\title{
Resolving challenges in tailings closure in semi-arid deserts - a case study into the decommissioning and rehabilitation of the Tanami Mine Three Cell tailings storage facility
}

\author{
K.L. Pang Outback Ecology, Australia \\ H.W.B. Lacy Outback Ecology, Australia \\ R. Haymont Newmont Asia Pacific, Australia \\ R. Potts Newmont Asia Pacific, Australia
}

\begin{abstract}
Tanami Mine, located within the Tanami Desert of the Northern Territory, approximately $670 \mathrm{~km}$ northwest of Alice Springs, is one of the most remote mine sites in Australia. The site comprises 45 open pits, eight backfilled pits, 11 in-pit tailing storage facilities (TSF), 24 waste rock landforms, two above ground TSF, a processing plant and on-site village accommodation scattered over $70 \mathrm{~km}$ in length.

The mine site, including TSF, has been subject to a systematic closure process over the last five years. The large Three Cell above ground paddock style TSF was seen by previous mine closure planners as a major challenge to rehabilitate, and accordingly had attracted the largest portion of the closure budget. Deposition of tailings into the TSF occurred between 1992 and 2001, and from this time the cells were allowed to dry and consolidate. The decommissioning process for the facility began in 2004, and a staged and logical approach was employed. Early in the process a review of literature and prior investigations was undertaken to identify gaps in information. The resolution of identified gaps required geochemical investigations for acid base chemistry and multi-elements, surveys of density of deposited tailings, compaction reduction studies through ripping trials with different dozers, ripper depth and configurations, geotechnical assessment of the existing walls, and an extensive upper surface closure option review, followed by a field trial to determine optimum cover designs for rehabilitation and closure.
\end{abstract}

Planning for tailings closure can often be a two to three year process, or longer for more problematic tailings stored in complex facilities, or facilities located on mine sites that have competing resource requirements. At the time of writing this paper, the closure earthworks for the Three Cell TSF were in the final stages, resulting in an active closure process of five years duration. It is expected that by late 2009 all earthworks will be complete and an "as-built decommissioning report" will be prepared. The site will then move into the monitoring phase.

The closure of the TSF has not been without challenges and included a one in 910 year annual exceedance probability (AEP) rainfall event which produced large-scale surface water flow and erosion. Other challenges included drought conditions, cold winters, extreme summer temperatures and perceived edaphic difficulties. This paper presents the process employed for the closure of the Three Cell TSF, the investigations, the issues encountered and the final closure strategy.

\section{Introduction}

The Tanami Mine site, owned by Newmont Asia Pacific, is a historic site which was initially mined for gold in the early $1900 \mathrm{~s}$, and most recently from mid 1980 to 2004 . The site has had numerous operators since 1987 Zapopan NL, Otter Gold Mines Ltd and AngloGold Australia Ltd (forming the Tanami Mine Joint Venture) and more recently Newmont Asia Pacific. Processing of ore ceased in August 2005 and since this time the site has been in a phase of decommissioning (Newmont Australia, 2006a).

Deposition of tailings into the Three Cell TSF occurred between 1992 and 2001. Since this time the TSF has been subject to a systematic closure process and this paper describes the investigations, the issues 
encountered, the final closure strategy and works programme. At the time of writing this paper the mine site and the TSF were in the final phase of decommissioning and rehabilitation earthworks.

\section{Locality and environment}

The Tanami Mine site is possibly one of the most isolated mine sites in Australia, located approximately $670 \mathrm{~km}$ northwest of Alice Springs, within the Tanami Desert of the Northern Territory (Figure 1). The Tanami region is sparsely inhabited. The nearest settlements are Lajamanu and Balgo, located approximately $230 \mathrm{~km}$ north and $200 \mathrm{~km}$ northwest of the Tanami mine, respectively. Rabbit Flat Roadhouse and The Granites Gold Mine are located $40 \mathrm{~km}$ and $100 \mathrm{~km}$ southeast of the Tanami mine, respectively. The majority of the project area occurs within the Central Desert Aboriginal Land Trust, administered by the Central Land Council (CLC) with much of the land in the area being of high ceremonial and cultural value. The land in the immediate mine area is not utilised for pastoral purposes.

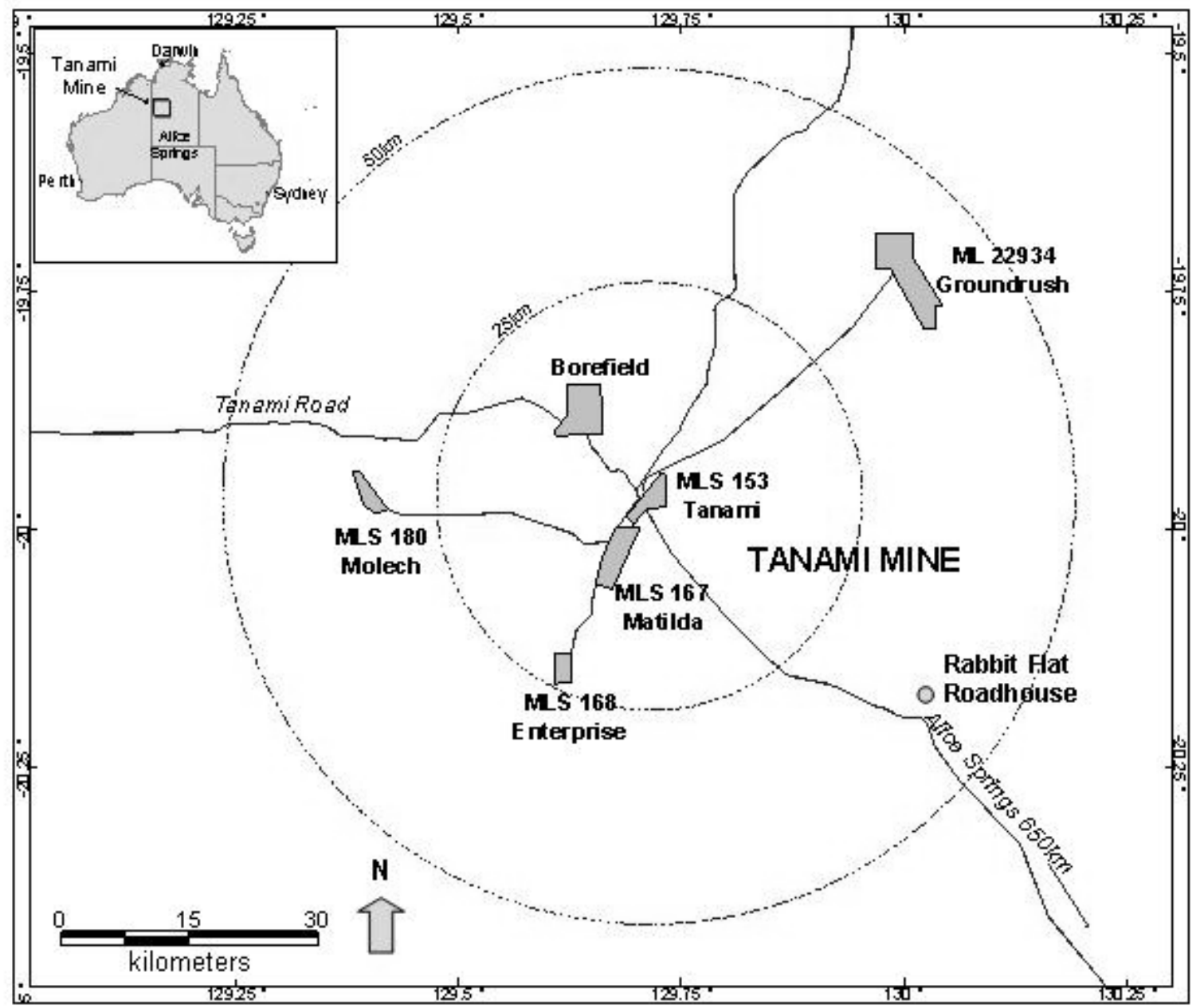

Figure 1 Location of Tanami Gold Project (Newmont Australia, 2004)

The region experiences harsh climatic conditions with hot summers and cold winters, variable rainfall leading to drought or flood events, endures frequent wildfires and is located within a semi-arid zone (Thomas, 1989). The majority of rainfall occurs between November and April and the closest Bureau of Meteorology station (Rabbit Flat) receives an annual average rainfall of $430 \mathrm{~mm}$ (Bureau of Meteorology, 2009). Rainfall has also been measured at Tanami since January 1988 and over the 21 year period recorded an average annual rainfall of $463 \mathrm{~mm}$, with the highest rainfall occurring in 2001 when $970 \mathrm{~mm}$ was recorded. The lowest annual total rainfall on record occurred in 1989 when $175 \mathrm{~mm}$ fell. Temperatures are variable with the hottest month of December recording a mean maximum temperature of $39.2^{\circ} \mathrm{C}$, and the coolest month of July recording a mean minimum temperature of $6.6^{\circ} \mathrm{C}$ (Bureau of Meteorology, 2009). 
The land surrounding the mine comprises of low sandy soil plains with minimal relief, containing tall open Acacia shrub land and low woodland with mainly spinifex and hummock grasses as understorey (Newmont Tanami Operations, 2008).

The mine site and its satellite pits are scattered over a length of $70 \mathrm{~km}$ adjacent to the Tanami Road. The Three Cell TSF is in close proximity to the processing plant and on-site accommodation village. The facility is a standard paddock styled structure comprising of three cells, each approximately 25 ha in area (Figure 2). At the time of writing this paper the facility was in the final stages of closure.

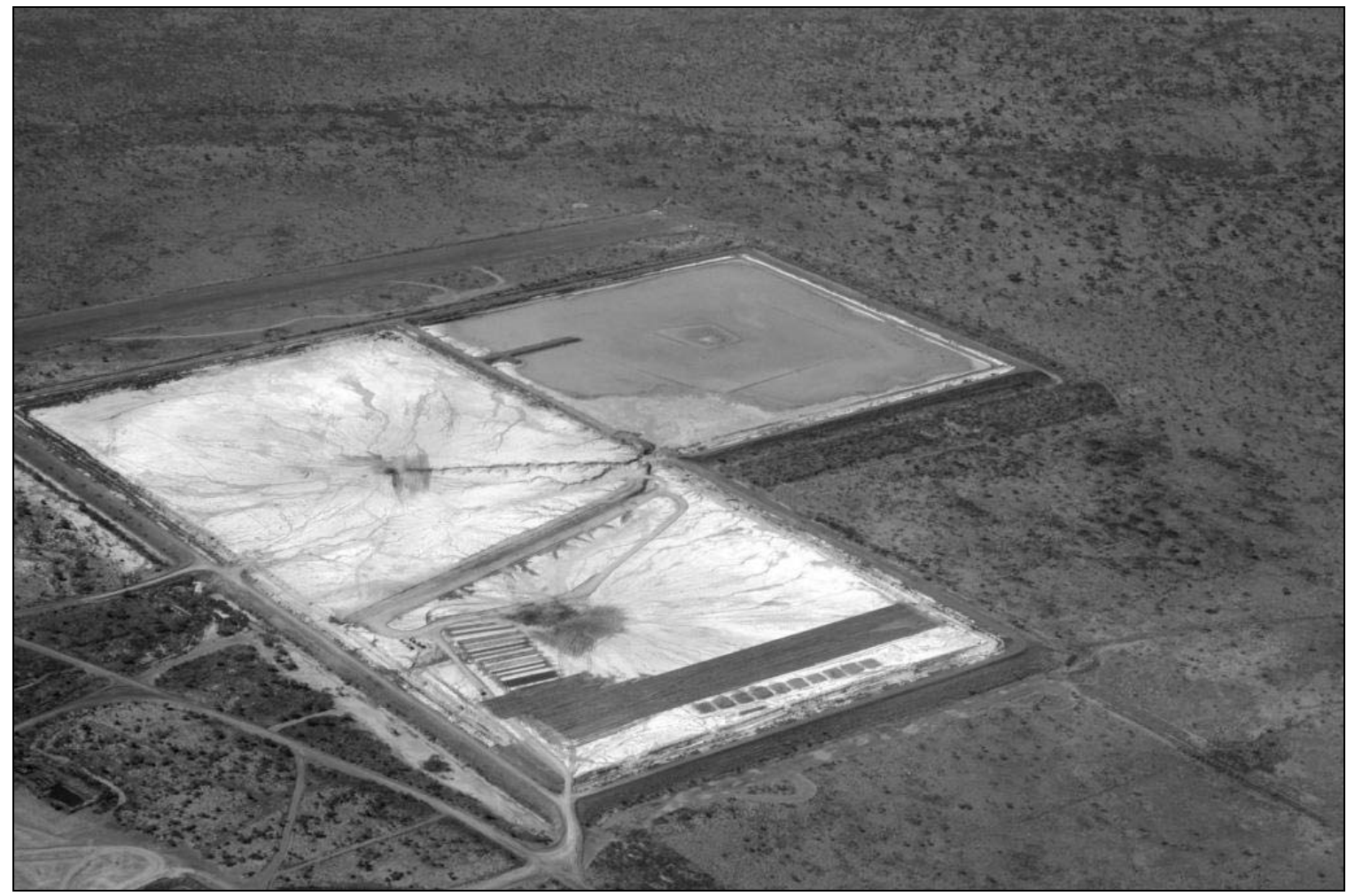

\section{Figure 2 Aerial view of Cells 1, 2 and 3 (taken prior to closure works) with trial works in the foreground}

\section{Closure process and teamwork}

At this point the author would like to distinguish the difference between decommissioning and closure. Decommissioning refers to the process that begins near, or at, the cessation of mineral production and ends with the removal of unwanted infrastructure and services. Closure relates to the whole of mine life process and includes both decommissioning and rehabilitation (Department of Industry Tourism and Resources, 2006).

The process used to decommission and close the TSF involved a staged approach. This process ensures an appropriate and acceptable procedure is followed and that closure occurs in a logical sequence. This approach has been described in a number of publications (Lacy and Campbell, 2000; Lacy, 2005; Lacy and Barnes, 2006) and has been presented to regulators of Western Australia and the Northern Territory. The steps are logical and involve a sequence of:

1. Stakeholder discussions, site visit and document review.

2. Sampling, investigations and research to define tailings properties and rehabilitation materials. In association with other specialists (where required) resolution of closure issues.

3. Preparation of the Draft Decommissioning Plan for submission to regulators.

4. Decommissioning and closure of the TSF and preparation of a Final Decommissioning Report.

5. Monitoring and sign-off. 
Results of the stages one and two work programme provided a solid understanding of the TSF and guided planners towards a particular closure design. Stakeholder engagement during operation and early in the closure process is a key to successful closure with agreed outcomes. Newmont have consulted regularly with Northern Territory regulators and the CLC to provide a forum for opinion and communication of the closure process. Progress of the overall mine closure plan is interpreted and discussed in regular meetings on- and off-site and during visits by stakeholders (Newmont Australia, 2006b). A closure plan detailing the mine site closure works that have been completed and are planned is updated annually and submitted to the CLC for their information, review and comment.

Furthermore, stakeholders that are involved in closure planning can provide input and influence the final landform designs affecting closure work. For example, realising the requirement for further tailings disposal, the local traditional owners allowed the backfill of open pits with tailings at Tanami and Granites Mine sites (Dowd and Slight, 2006). This eliminated the need to build new storage facilities and as a consequence the Tanami has 11 in-pit facilities and the nearby Granites Mine, four.

A review of literature is critical at the initial stage of closure planning as it provides an understanding of the facility, identifies key issues and risks and reveals conditions and commitments previously made, all of which the closure team must be cognisant of. Following the collation and summation of all literature a number of gaps in knowledge were exposed. Investigations to remedy these gaps were designed and implemented. The investigations were primarily related to rehabilitation and are described in more detail in subsequent sections. Based on an internal literature review, gap analysis and investigative work, the key closure risks were assessed and an appropriate closure strategy was developed.

\subsection{Teamwork}

Newmont Asia Pacific has developed a specialised closure and reclamation team. This team facilitates the delivery of Newmont's closure standards throughout Newmont's Australasian operations. As described in Haymont et al. (2008) successful closure and rehabilitation can be achieved by attracting personnel with a range of relevant skills and knowledge. This can be achieved by developing specialist teams within companies and utilising specialist contractors to carry out closure and rehabilitation works. These teams can manoeuvre from site to site as required, and carry forward diverse experience from past closures, to present and future challenges. The authors believe building and maintaining these teams is a key factor in achieving successful mine closures.

The team used for the closure of the TSF comprised of 15-20 specialists from Newmont regional and site based areas, consultants and earthworks contractors. These people were directly involved in a range of tasks including planning, investigation and assessment, stakeholder liaison, reporting, cost analysis, implementation and rehabilitation earthworks. Many of the individuals have had experience in numerous mine closures, rehabilitation earthworks and tailings decommissioning.

\section{$4 \quad$ Background information and gap analysis}

As the name suggests, the Three Cell TSF is comprised of three cells. Cells 1 and 2 were constructed over the period 1992 to 1994 (Australian Tailings Consultants, 2003) and were used until 1997, whereupon Cell 3 was built to increase storage capacity and allow Cells 1 and 2 to dry and consolidate. Tailings deposition continued into Cell 3 until the end of 2001 (Newmont Australia, 2006b) and the decommissioning process began shortly after.

The embankments were constructed with mine waste via the upstream method. Between 1999 and 2001 central spigots discharged tailings and resulted in the formation of a central raised cone. As a result, incident rain reported to the edge of the facility and a drain was created around the walls of Cells 1 and 2 to convey water to Cell 3 via an incision in the Cell 2/3 wall. The relative elevation of Cell 3 is lower than Cells 1 and 2, and freeboard in Cell 3 was considerable at around 2-3 m. Cell 3 was in effect an evaporation basin for the incident rain that fell on the TSF (Outback Ecology, 2007; Australian Tailings Consultants, 2003).

Geotechnical assessments revealed the facility was stable, with the factor of safety for all cell walls greater than that required by regulation. The outer batters of Cells 1,2 and 3 were variable in slope angle (between 23-25 degrees), relatively short and ranged from 5-12 m in length (Newmont Australia, 2006b). Cell 3's 
walls were higher, ranging from $12-19 \mathrm{~m}$, and steeper from $24-31^{\circ}$. The profile design of the upper surface for closure was unknown and a surface water management strategy to cater for large scale rainfall events was required. Hence, surface water management was identified as a gap in information.

A review of groundwater conditions in 2004 revealed a total rise in groundwater levels near Cells 1 and 2 of between 10-15 m from 1992 to 2001. A comparison of groundwater level time-trend data suggested groundwater mounding beneath the footprint of the TSF in 2006 remained fairly constant since cessation of tailings discharge in 2001. In terms of groundwater quality in 2006, the monitoring bores in the vicinity of the TSF remained fairly consistent with little or no impact from tailings seepage. The exception to this was one bore which showed evidence of tailings seepage (Robertson GeoConsultants Inc., 2006).

In terms of geochemistry the tailings were found to be non-acid forming (NAF) based on total sulphur, acid neutralisation capacity (ANC) and net acid producing potential (NAPP) laboratory assessment and calculations. They had moderate concentrations of arsenic and copper, although these were not considered excessive by the geochemists. It was, however, recommended arsenic be included in the routine water quality monitoring suite (Environmental Geochemistry International Pty Ltd, 1995; Graeme Campbell and Associates, 2006). Properties of the tailings that are relevant to physical structure (sodium absorption ratio and cation exchange capacity) and revegetation (nutrients) are provided in Tables 1 and 2 respectively (electrical conductivity (EC) and $\mathrm{pH}$ of the tailings are discussed in Section 5.2).

In terms of rehabilitation mediums, a number of waste landforms in close proximity to the TSF were identified as potential sources for cover materials. The suitability of these materials as covers was investigated and a sampling and analysis programme conducted. The material characterisation programme involved assessment for paste $\mathrm{pH}$ and $\mathrm{EC}$, in situ moisture content, cation exchange capacity, stone durability, exchangeable sodium percentage, $x$-ray diffraction testing and particle size distribution. From this assessment the Central and Airstrip waste landforms were found to be the most suitable materials available (O'Kane Consultants Pty Ltd, 2004). The water retention characteristics, plant available water content and geochemistry and mineralogy for these materials were unknown.

In 2004, a draft closure approach recommended the application of a 1.25-2 m cover, comprising a layer of fine material to act as a seal overlaid by coarse material and topsoil for revegetation. The suitability and the purpose of the recommended closure cover profile was questioned by the Newmont closure team, and it was decided further investigation was required to determine an optimum cover for the specific conditions of the TSF.

Following this, a review of literature relevant to the TSF and assessment of tailings properties was conducted. The review noted the major impediment to rehabilitation would be high EC (ranging from approximately $7.1-9.6 \mathrm{dS} / \mathrm{m}$ at the surface and less than $1.0 \mathrm{dS} / \mathrm{m}$ at depths greater than $20 \mathrm{~cm}$ ). After consideration of the tailings properties and review of literature, an alternative cover programme that enhanced infiltration and salt leaching, and encouraged water storage in the cover was suggested.

Factors relevant to the success of revegetation and establishment of a sustainable vegetation community on the TSF were identified as gaps in information. In particular the properties of the tailings that affect plant establishment and growth (such as $\mathrm{EC}, \mathrm{pH}$ and moisture content) and their movement within the tailings and cover profiles, the tolerance of endemic, native species to survive in these substrates, and the optimum cover depth and design, were considered unknown and worthy of investigation. A series of investigations and trials were established to resolve these issues and the following section describes these in more detail.

Table 1 Sodium absorption ratio (SAR) and cation exchange capacity (CEC) of bulked tailings samples (Outback Ecology, 2006a)

\begin{tabular}{llll}
\hline Site & Sample Depth $(\mathbf{c m})$ & SAR & CEC (meq/100 g) \\
\hline Cell 1 & $5-10$ & 19.1 & 16.8 \\
Cell 2 & $5-10$ & 16.1 & 16.8 \\
Cell 3 & $5-10$ & 13.5 & 12.9 \\
\hline
\end{tabular}


Table 2 Plant available nutrients (nitrogen (N), phosphorus (P), potassium (K)) in bulked tailings samples in comparison with topsoil (Outback Ecology, 2006a)

\begin{tabular}{lllllll}
\hline & & $\begin{array}{l}\text { Sample } \\
\text { Depth }\end{array}$ & $\begin{array}{l}\text { Nitrate } \\
\text { N }\end{array}$ & $\begin{array}{l}\text { Ammonium } \\
\mathbf{N}\end{array}$ & $\begin{array}{l}\text { Phosphorus } \\
(\mathbf{P})\end{array}$ & $\begin{array}{l}\text { Potassium } \\
\mathbf{( K )}\end{array}$ \\
\cline { 3 - 7 } Cite & Material & $\mathbf{c m}$ & $\mathbf{m g} / \mathbf{k g}$ & $\mathbf{m g} / \mathbf{k g}$ & $\mathbf{m g} / \mathbf{k g}$ & $\mathbf{m g} / \mathbf{k g}$ \\
\hline Cell 1 & tailings & $15-20$ & 17 & 1 & 6 & 400 \\
Cell 2 & tailings & $30-40$ & 49 & 1 & 4 & 253 \\
Cell 3 & tailings & $15-20$ & 18 & 1 & 3 & 188 \\
Topsoil & topsoil & N/A & 14 & 5 & 5 & 130 \\
\hline
\end{tabular}

\section{$5 \quad$ Resolution of cover profile and surface design}

\section{$5.1 \quad$ Ripping assessment}

The bulk density of the tailings to two metres depth was found to range from $1.40-1.66 \mathrm{~g} / \mathrm{cm}^{3}$. In comparison three rangeland sites nearby tested $1.49-1.77 \mathrm{~g} / \mathrm{cm}^{3}$, and although a similarity is noted, it was determined that these dense tails required modification. Following assessment of multiple and single tyne ripper assemblages, and as part of the tailings trial, a small scale ripping assessment of the tailings was conducted. The objective of the assessment was to determine the optimum method to break up the compact dense, clay rich tailings to assist moisture entering the tailings, facilitate salt leaching down through the profile and enhance root penetration. Two forms of ripping methods were applied:

- Single tyne ripping at $1.3 \mathrm{~m}$ depth and $1 \mathrm{~m}$ spacing.

- Single tyne ripping at $1.3 \mathrm{~m}$ depth and $2.5 \mathrm{~m}$ spacing.

A test pit was excavated across the profile of the ripped trial area. Marked visual differences were observed in the level of tailings fracture between the two methods. It was found that the $1.3 \mathrm{~m}$ depth and $1 \mathrm{~m}$ spacing appeared to have been more effective than the $2.5 \mathrm{~m}$ spacing. As a result of these initial findings and prior to the final cover being placed, a dozer (larger than used in the trial) with a large two metres deep winged tyne was used to shatter the dense tails profiles of Cells 1 and 2 to a depth of $1.7 \mathrm{~m}$, at a spacing of approximately $2.5 \mathrm{~m}$. The use of a larger machine with a winged ripper caused greater shattering of the tails to facilitate salt leaching during rainfall events and will enhance plant roots penetration. Cell 3 was not ripped prior to cover placement, but was ripped after cover placement to a depth of $\sim 1-1.3 \mathrm{~m}$. To prevent tailings exposure on the upper surface the top wing of the tyne was used in the upper 300-400 $\mathrm{mm}$.

\subsection{Field trial}

A tailings trial was established on the upper surface of the TSF in 2005 as part of the decommissioning investigation process. The objective was to test the effectiveness of various rehabilitation techniques on the tailings material for plant establishment and growth and to determine the optimum cover profile for the facility.

Initial sampling of tailings material to identify the nature of the tailings was conducted in June 2005. Samples of tailings were collected and assessed for $\mathrm{pH}$ and EC (Table 3).

Table 3 Properties of tailings pre-trial (June 2005) (Outback Ecology, 2006b)

\begin{tabular}{llll}
\hline Parameter & Depth $(\mathbf{c m})$ & & \\
& $\mathbf{0 - 5}$ & $\mathbf{5 - 1 0}$ & $\mathbf{3 0 - 4 0}$ \\
\hline $\mathrm{pH}$ & 8.5 & 9.1 & 9.3 \\
$\mathrm{EC}(\mathrm{dS} / \mathrm{m})$ & 4.9 & 1.6 & 0.8 \\
\hline
\end{tabular}


Six cover treatments, including a control, were chosen for the trial (Table 4). These treatments were selected as they represented the most viable range of possible cover options for the upper surface of the TSF. Material from the Central waste rock dump, mill scats and topsoil were used in the trial at varying combinations and depths and compared with a bare control plot. Following from the initial assessment of Central waste dump material as described in section 4, the geochemist found the Central dump regolith was circum-neutral $\mathrm{pH}$, contained a moderate content of soluble salts when compared to other potential cover materials and rehabilitation areas at Tanami Mine site, and was essentially geochemically harmless, thus suitable as a cover.

Two replicate plots were constructed for each treatment with the dimensions of each plot being $15 \times 15 \mathrm{~m}$ $\left(225 \mathrm{~m}^{2}\right)$. Prior to cover placement, the tailings were deep ripped to $1.2 \mathrm{~m}$ depth at $1 \mathrm{~m}$ spacing as per the findings of the ripping assessment. Cover materials and topsoil (Figure 4a) were placed on the ripped tailings and all plots were shallow ripped to $30-40 \mathrm{~cm}$ depth at $1.5 \mathrm{~m}$ spacing. Seed from fifteen local species were applied within a seed mix that comprised of Acacia and Chenopod species that can tolerate alkaline/saline soil conditions. The seed mix was applied at a rate of $6.95 \mathrm{~kg} / \mathrm{ha}$ and supplemented the unknown quantity of seed stored within the topsoil.

Table 4 Cover treatments tested in field trial (Outback Ecology, 2009)

\begin{tabular}{ll}
\hline Treatment Code & Description \\
\hline T1 & $10 \mathrm{~cm}$ topsoil placed on $15-20 \mathrm{~cm}$ waste rock \\
T2 & $10 \mathrm{~cm}$ topsoil placed on $50 \mathrm{~cm}$ waste rock \\
T3 & $10 \mathrm{~cm}$ topsoil placed on $90 \mathrm{~cm}$ waste rock \\
T4 & $10 \mathrm{~cm}$ topsoil placed on $20 \mathrm{~cm}$ mill scats \\
T5 & $10 \mathrm{~cm}$ topsoil placed directly on tailings \\
T6 & Control (bare tailings) \\
\hline
\end{tabular}

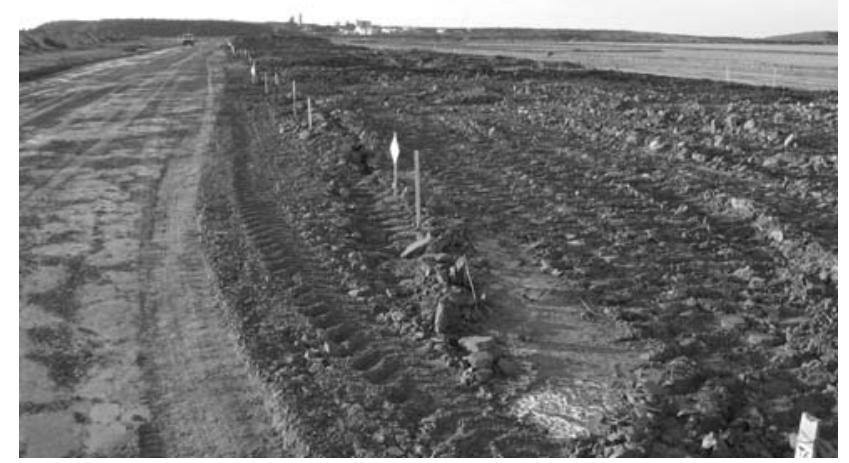

(a)

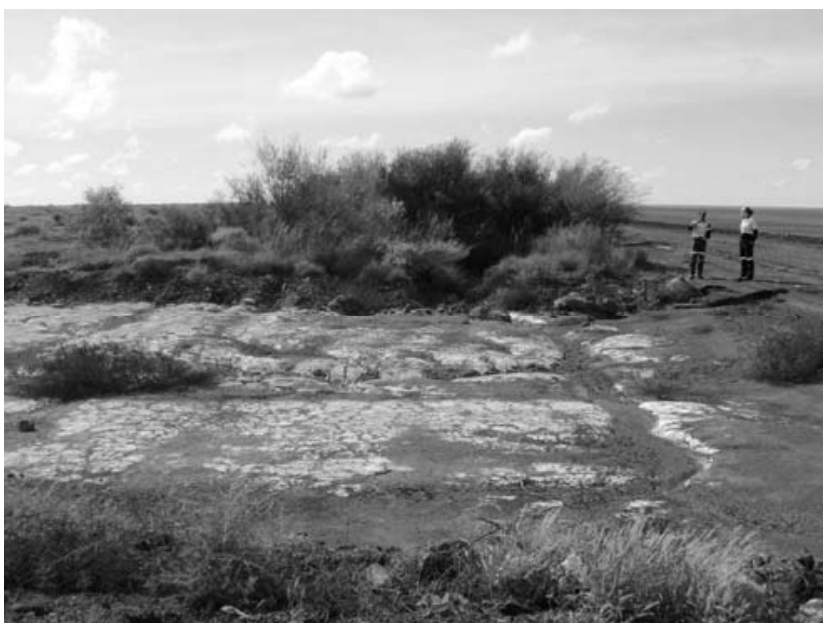

(b)

Figure 4 (a) Field trial on Cell 1 near completion (December 2005) looking in a westerly direction; (b) Treatment 2 (background) comprising $10 \mathrm{~cm}$ topsoil over $50 \mathrm{~cm}$ waste rock (August 2008) proved to be the most successful treatment. A control treatment plot is shown in the centre

At the time of writing this paper the trial was approximately three years old and had been assessed annually. The cover treatments produced variable results with the success of rehabilitation being dependent on a number of physical, chemical and biological factors.

Two treatments were identified as performing well across all parameters measured in the recent assessment conducted in August 2008 (Outback Ecology, 2009). Treatment 2 (Figure 4b), which was the second deepest 
cover treatment (10 cm topsoil and $50 \mathrm{~cm}$ waste rock), recorded the highest plant density, highest plant cover and the third highest species diversity (Figure 5). Furthermore, the treatment recorded the lowest average tailings EC (Figure 6). One of the shallower cover treatments (Treatment 4), comprising of $10 \mathrm{~cm}$ topsoil and $20 \mathrm{~cm}$ mill scats, recorded the second highest plant cover, third highest plant density value and the lowest average EC of all cover materials.

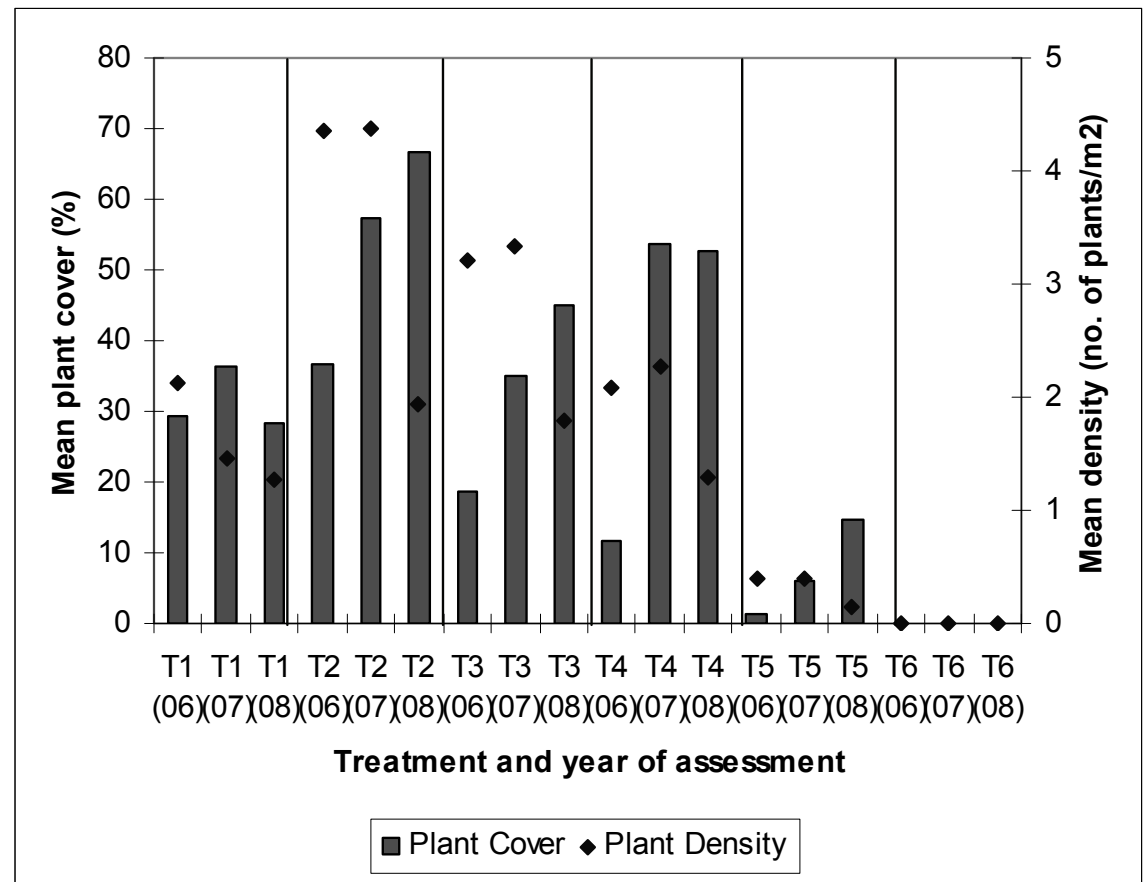

Figure 5 Mean plant cover (\%) and mean plant density (number of plants $/ \mathrm{m}^{2}$ ) for each treatment. The year of assessment is shown in parenthesis (Outback Ecology, 2009) 

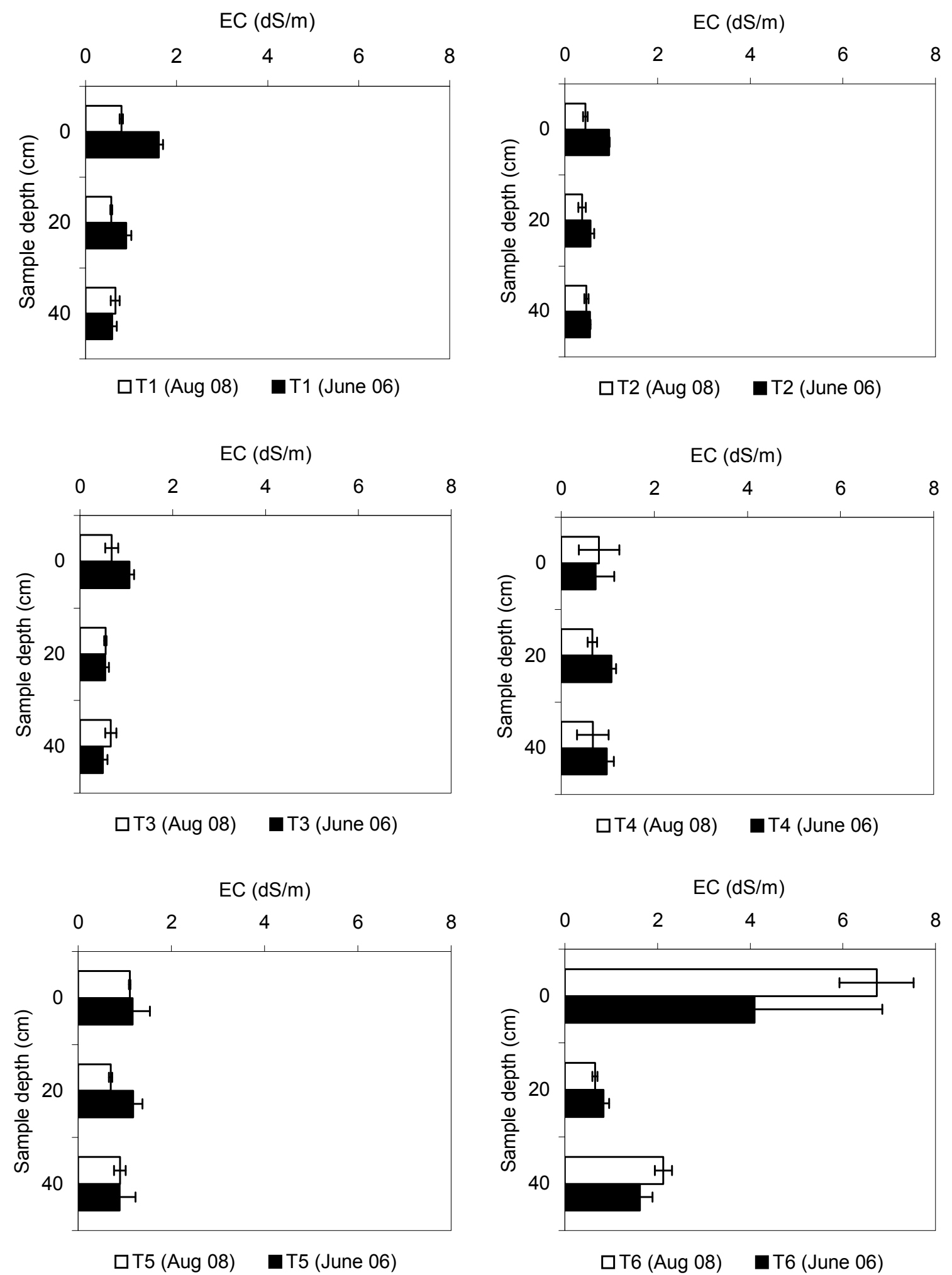

Figure 6 EC of bulked tailings from each treatment (Treatment 1-6) in June 2006 and August 2008 with depth, $\mathbf{n}=2$ (Outback Ecology, 2009) 
Generally, EC of the tailings material declined from the initial values recorded in November 2005 with only the control (Treatment 6) reporting an increase as a result of capillary rise of salts at surface. The decline of EC within the tailings profile under the cover is most likely a combination of salt mobilising from the tailings and leaching deeper into the profile and/or moving upward into the cover material via capillary rise. This was evident with the decline within the tailings material and a gradual increase of the cover materials EC over the trial period.

As with the findings of the recent trial assessments (September 2007 and August 2008), the moisture content of the cover materials were statistically different between treatments and generally corresponded to the depth of the cover treatment. The deeper treatments generally recorded higher moisture contents, whereas the shallower treatments recorded the opposite. In terms of moisture content within the tailings, the control (Treatment 6), which was without a cover, consistently recorded one of the lowest moisture contents of all treatments. Surprisingly, there appears to be no large or discernable pattern or difference with regard to the deeper cover treatments and the moisture content of the underlying tailings.

From the commencement of the trial, the control (Treatment 6) performed poorly in terms of tailings chemistry and plant growth. The tailings material recorded the highest salinity of all treatments and vegetation was absent. Salt concentrated on the tailings surface is due to capillary rise (Figure 4b).

Six plant species from a possible fifteen were identified as originating from the seed mix that was applied to the plots in 2005. These species were Acacia inaequilatera, A. kempeana, A. pruinocarpa, A. stipuligera, A. victoriae and Atriplex vesicaria. Many of the species recorded in the plots germinated from the topsoil.

Based on the results of the tailings trial, the cover design selected for use on Cells 1 and 2 was Treatment 2 (10 $\mathrm{cm}$ topsoil and $50 \mathrm{~cm}$ waste rock). Following ripping of tailings and application of the cover layer and topsoil, the surface was shallow ripped to $30-40 \mathrm{~cm}$. The cover design for Cell 3 was slightly different and is described in the following section.

\subsection{Surface design}

Control of surface water runoff during high rainfall events was initially considered a major design challenge in closure of the TSF. The consulting engineers were engaged to determine a plan for the management of surface water runoff for closure (Australian Tailings Consultants, 2006).

A series of surface water management designs were investigated and included a large rainfall event (AEP 1-in-100 years), rare rainfall event (1-in-200 years), extreme rainfall event (1-in-2000 years), probable maximum precipitation (PMP) event and 50 per cent of the PMP event.

Due to central discharge points in these cells and creation of mounds at the final stages of deposition, there was a lack of freeboard on Cells 1 and 2 and surface water runoff produced on these cells was discharged into Cell 3. Subsequently design for closure was dependent on Cell 3 maintaining adequate freeboard to contain runoff from Cells 1 and 2, in addition to incident rain falling on Cell 3.

After discussion and reviews of options, it was decided to implement a design that allowed water to collect in Cells 1 and 2, flow into a 1-in-100 year design stormwater drain situated around the perimeter of the cells, and discharge into a drop structure constructed along the common embankment between Cells 2 and 3. To prevent overtopping of Cell 3 in the event of an extreme rainfall occurrence, an emergency spillway from Cell 3 was to be constructed.

The storage capacity of Cell 3 was up to $354,000 \mathrm{~m}^{3}$ of water. This equates to a rainfall depth of $472 \mathrm{~mm}$ falling over all three cells, or approximately the PMP event for one hour duration. Hence, rainfall up to the PMP event for a one hour duration can be stored in Cell 3. In January 2006, prior to closure earthworks as described above, a 1-in-910 year rainfall event was received. This equated to $486 \mathrm{~mm}$ falling in a 72 hour period (A. Vitale, pers. comm., 2006). The event demonstrated Cell 3's capacity to store all catchment runoff water from the upper surface of Cell 1,2 and 3 prior to the existing earthworks programme.

To protect the stormwater drain and spillway, the water management structures were constructed with $50 \mathrm{~cm}$ compact coarse waste rock on top of tailings. The stormwater drain is trapezoidal in cross section and has a width of $30 \mathrm{~m}$. The outfall structure between Cells 2 and 3 is $400 \mathrm{~m}$ wide. The emergency spillway has not yet been constructed and will be a rock lined drop down structure approximately four metres high and $45 \mathrm{~m}$ 
wide. The emergency spillway will discharge water into the surrounding environment rather than overtopping and potentially breaching the wall in an uncontrolled manner. The spillway will be located on the northwestern end of Cell 3 and will discharge water when rainfall events exceed the storage capacity of Cell 3 (PMP or less events). Discharged water would pond to the north of the TSF, evaporate and/or infiltrate into the soil.

To slow water runoff and enhance infiltration into the deeply ripped tailings on the upper surface of Cells 1 and 2, concentric bunds were constructed. In contrast, the central area of Cell 3 is dish shaped, with a lower area that will provide an ephemeral wetland. This area was covered with the more competent waste rock and topsoiled.

The Cell 1 and 2 walls required no further re-profiling during closure works as they were stable with little erosion present and approximately 50 per cent of the slope area naturally revegetated. The walls of Cell 3 were considered too steep, had minimal revegetation and although geotechnically stable and unlikely to fail, would be prone to erosion in the long term. To reduce the slope angle, mitigate potential erosion in the long term and to provide a suitable environment for revegetation it was decided to buttress sections from the base.

\section{$6 \quad$ Perceived risk and risk assessment}

A risk assessment was conducted to identify potential hazards and determine respective levels of risk, before and after closure earthworks. The risk assessment was used to determine priority areas in order to plan and apply appropriate management strategies. The primary unmanaged hazards identified during the risk assessment include water erosion and structural instability, dust, seepage into groundwater and vegetation failure due to poor tailings properties and/or water erosion. The perceived, unmanaged hazards and respective level of risk was reduced by a series of controls. Some of the control measures, as described in previous sections, included characterisation of tailings to determine geochemistry and properties suitable for plant growth, characterisation of potential cover materials and application of surface cover, to revegetate with species suitable for the site conditions, buttressing slopes to a more suitable angle and length to prevent erosion, ripping on contour and installation of bunds, provision of an emergency spillway for excessive rainfall events, bunding to restrict and limit human access and post-closure monitoring.

\section{$7 \quad$ Monitoring}

Upon completion of the final earthworks which include buttressing of walls, construction of the emergency spillway, and re-survey of the upper surface (to confirm capacity to contain rainfall events to design following application of the soil cover), an As-built Decommissioning Report will be prepared.

Furthermore, to ensure the rehabilitation is performing adequately and in a sustainable manner, an Ecosystem Function Analysis (EFA) monitoring programme has been initiated on the TSF, and the larger Tanami Mine site. EFA is a monitoring tool that assesses the success of rehabilitation areas in terms of stability, infiltration and nutrient cycling indices as well as vegetation growth and erosion. The TSF has been monitored with EFA for three years and is showing encouraging results. Ongoing monitoring will determine the degree of success and if the rehabilitation is trending towards the analogues and is stable and sustainable (Tongway, 2008).

Groundwater monitoring will continue post closure. Groundwater is measured for levels and quality parameters such as $\mathrm{pH}, \mathrm{EC}$, total dissolved solids (TDS), sulphate $\left(\mathrm{SO}_{4}\right)$, arsenic and a range of selected trace metals. Groundwater monitoring will provide an indication of the long term success of the closure design. To date, post-closure earthworks have shown groundwater quality near the TSF remains relatively unaffected by tailings seepage (Robertson GeoConsultants Inc., 2009). This may indicate ponded water is either stored in the upper layers of the cover/tailings profile, evaporated from the surface and/or evapotranspired by vegetation, thus limiting water infiltration into the groundwater system. However it is likely some of the water produced during infrequent storm events, and is stored on Cell 3, will infiltrate into the tailings and percolate into the groundwater, causing fluctuations in levels. 


\section{Conclusions and summary}

Tanami Mine and the Three Cell TSF are in the final stages of decommissioning and rehabilitation. The closure of the TSF involves a lengthy process of planning, investigations, trials and resolution of closure challenges, monitoring towards success criteria and possible adjustments. The final closure strategy involved deep ripping the tailings, overlaid by a cover comprising of $50 \mathrm{~cm}$ waste rock and $10-20 \mathrm{~cm}$ topsoil. The design allows for water produced from large scale storm events to overtop the drainage controls on Cells 1 and 2 but remain contained within a stormwater channel situated around the perimeter of both cells. An outfall structure between the common embankment of Cells 2 and 3 will convey excess stormwater from Cells 1 and 2 to Cell 3. An emergency spillway on Cell 3 will ensure the integrity of the system in the event of the rainfall exceeding the storage capacity of Cell 3 .

Based on scientific investigations and trials, it has been determined that the materials stored within the TSF are relatively benign in terms of edaphic factors and geochemistry when compared to other tailings facilities in semi-arid areas of Australia. The closure process employed has reduced the perceived risk to an acceptable level, although as with all mine closure residual risks remain. Rehabilitation and groundwater monitoring will provide an indication of the success of the closure, and if risks associated with the facility have been appropriately mitigated. Based on field trials and an understanding of the tailings properties, it is hoped that the facility will be able to support plant growth in the long term. At the present time vegetation is flourishing on both the trial site and Cells 1 and 2.

Newmont Australia's aspirations are that the Three Cell TSF will gradually integrate itself back into the surrounding open Acacia shrub land and spinifex hummock grassland environment, whilst causing minimal disruption and pollution to the surrounding ecosystem. Upon closure and relinquishment of the lease, the land will be managed once again by the traditional owners. An effective staged and logical sequence was used for the closure of the Three Cell TSF. The expertise of a multi-disciplinary closure team was utilised to fulfil knowledge gaps and resolve closure issues. This case study highlights how an effective tailings closure strategy and plan can be achieved by leadership, questioning assumptions, application of scientific process, commitment and perseverance.

\section{Acknowledgements}

The authors would like to thank all those who were involved in the closure process of the facility. Special thanks to Australian Tailings Consultants (now ATC Williams), Graeme Campbell and Associates and Cardinals Earthmoving Contractors.

\section{References}

Australian Tailings Consultants (2006) Tailings Storage Facility Closure Studies Report on Proposed Hydraulic Design for Tailings Surface Runoff, Newmont Australia Tanami Operations, Victoria, internal report, 23 p., (unpublished).

Australian Tailings Consultants (2003) Tanami Mine - Walkover Inspection of Perimeter Tailings Cells, 1, 2 and 3, Newmont Australia, Victoria, internal letter report, 13 p., (unpublished).

Bureau of Meteorology (2009) Climate statistics for Australian locations, viewed 16 July 2009, http://www.bom.gov.au/climate/averages/tables/cw_015548.shtml.

Department of Industry and Tourism Resources (2006) Mine closure and completion, leading practice sustainable development program from the mining industry, Commonwealth of Australia, Canberra, p. 63.

Dowd, P. and Slight, M. (2006) The Business Case for Effective Mine Closure, In Proceedings of the First International Seminar on Mine Closure, Mine Closure 2006, A.B. Fourie, M. Tibbett (eds), 13-15 September 2006, Perth, Australia, Australian Centre for Geomechanics, Perth, pp. 3-11.

Environmental Geochemistry International Pty Ltd (1995) Environmental geochemical assessment of mine rock and tailings, NSR Environmental Consultants Pty Limited, Hawthorn, internal report, 14 p., (unpublished).

Graeme Campbell and Associates (2006) Tanami Project: Testing Programme on Water-Retention Properties of Soil, Regolith and Tailings-Solids Samples, and Wicking-Column Testing of Regolith Sample, for Assessing Closure Options for the Tailings Storage Facility (TSF), Ref No: 0518/2, Bridgetown, In Outback Ecology (2006a) Integration of Technical findings from Site Investigations to Assist in Rehabilitation Planning at the Tanami Mine, Perth, internal report, 31 p., (unpublished).

Haymont, R., Clements, E. and Lacy, H.W.B. (2008) Closure through a process of collaboration: Suggestions as to how mining companies and contractors can work together to make closure processes successful, In Proceedings of the 
First International Seminar on the Management of Rock Dumps, Stockpiles and Heap Leach Pads, Rock Dumps 2008, A.B. Fourie (ed), 5-6 March 2008, Perth, Australia, Australian Centre for Geomechanics, Perth, pp. $147-150$.

Lacy, H.W.B. (2005) Closure and Rehabilitation of Tailings Storage Facilities, Developments in Minerals Processing, Vol. 15, M. Adams (ed), Elsevier BV, Amsterdam, Netherlands, Sect 1.4.2.

Lacy, H.W.B. and Barnes, K.L. (2006) Tailings Storage Facilities Decommissioning Planning is vital for successful closure, In Proceedings of the First International Seminar on Mine Closure, Mine Closure 2006, A.B. Fourie, M. Tibbett (eds), 13-15 September 2006, Perth, Australia, Australian Centre for Geomechanics, Perth, pp. 139-148.

Lacy, H.W.B. and Campbell, G. (2000) Decommissioning Tailings-Storage Facilities: The challenges and how they are being met during closure of a Nickel-Sulphide Mine in Western Australia, 4th International and 25th National Environmental Workshop, Minerals Council of Australia, Perth.

Newmont Australia (2004) Mining Management Plan 2003/2004, Granites MLS 8 (MLS 134-MLS 144), Dead Bullock Soak MLS 154, Minotaur ML 23283, Groundrush ML 22934, Tanami MLS 153 (Processing), Newmont Australia, internal report, 50 p., (unpublished).

Newmont Australia (2006a) Tanami Legacy Site - Closure Criteria Report (Draft Version 1), Newmont Australia, internal report, 13 p., (unpublished).

Newmont Australia (2006b) Newmont Legacy Sites - Tanami Mine Closure and Rehabilitation Plan, Management System and Record, Newmont Australia, internal report, 103 p., (unpublished).

Newmont Tanami Operations (2008) Mining Management Plan 2008, Draft February 2008, Granites MLS 8 (MLS 134 - MLS 144), Dead Bullock Soak MLS 154, Minotaur ML 23283, Newmont Tanami Operations, internal report, 60 p., (unpublished).

O'Kane Consultants Pty Ltd (2004) Development of a Cover System Design for the Newmont Australia Tanami Mine Joint Venture Operations, Phase One Final Report, Potential Cover and Tailings Dam Material Characterisation and Cover System Design Soil-Atmosphere Modelling, Newmont Australia, Brisbane, internal report, 48 p., (unpublished).

Outback Ecology (2009) Newmont Australia Tanami Mine, Tailings Research field Trial - Three Cell Tailings Storage Facility, Third year of assessment (February 2009), Newmont Australia, Perth, internal report, 27 p., (unpublished).

Outback Ecology (2007) Newmont Australia Tanami Gold Project, Tanami Three Cell Tailings Storage Facility (Cells 1, 2 and 3) Draft Decommissioning Plan (January 2007), Newmont Australia, Perth, internal report, 40 p., (unpublished).

Outback Ecology (2006a) Literature Review Tanami Mine TSF Closure (August 2006), Newmont Australia, Perth, internal report, 330 p., (unpublished).

Outback Ecology (2006b) Tailings Research Field Trials to Determine Cost Effective Rehabilitation Strategies, Tanami Mine, Three Cell TSF, Newmont Australia, Perth, internal report, 12 p., (unpublished).

Robertson GeoConsultants Inc. (2009) 2008 Groundwater Monitoring Report, Tanami Tailings Operations, Northern Territory, Australia, Newmont Australia, Vancouver, internal report, 19 p., (unpublished).

Robertson GeoConsultants Inc. (2006) 2005 Groundwater Monitoring Report Draft, Tanami Tailings Operations, Northern Territory, Australia, Newmont Australia, Vancouver, internal report, 24 p., (unpublished).

Thomas, D.S. (1989) Arid Zone Geomorphology, Belhaven Press, London, pp. 2-3.

Tongway, D. (2008) Facilitating Mine Closure with a Continuous Analysis and Review System, In Proceedings of the Third International Seminar on Mine Closure, Mine Closure 2008, A.B. Fourie, M. Tibbett, I.M. Weiersbye, P. Dye (eds), 14-17 October 2008, Johannesburg, South Africa, Australian Centre for Geomechanics, Perth, pp. 21-26. 